熱対流に和ける組織的構造につんて

Coherent structures in thermal convection

$\begin{array}{llll}\text { 埼玉大学工学部 } & \text { 正会員 浅 枝 } & \text { 隆 } \\ \text { 埼玉大学工学部 } & \text { 正会員 池 田 駿 介 } \\ \text { 埼玉大学 } & & \text { 宮 嘉 朗 }\end{array}$

1 はじめに

貯水池が水表面から冷却されていく時に生ずる様な非常に Rayleigh 数 $\left(=\alpha \Delta \operatorname{Tgd}^{3} / \kappa \nu\right)$ が大をな条件の もとで生ずる対流については、必ずしもその全貌が明らかになっているとはいえない。浅枝・玉井・高橋 ${ }^{1)}$ の可視化手法を用いた測定によると、非常に Rayleigh 数の大をな条件のるとで生じる対流は、スリット内 に生じるRayleigh 数の小さい対流と性質が異なり、その水平スケールもは、上端もしくは下端の境界から の浮カフラックス、動粘性係数、層厚の関数として定まるてとが明らかになっている。しかし、実際にはて の様に、Rayleigh 数の大をな領域で生ずる対流は、連続的もしくは間欠的に生ずる無数のプリュームで構 成されており、対流の強度を求めたり、現地の様に水深が非常に大をくなった状態を予測する上では、ての 様なプリュームと対流との関係を調べるととが不可欠である。本研究は、こうした対流内に生じるプリュー ムについて考察し、対流との関係について求めたものである。

\title{
2 実験装置および実験方法
}

実験は、熱フラックスの制御の容易さから下面から加熱する方法をとった。実験に用いた水槽の大をさは、 底面が $90 \mathrm{~cm} \times 90 \mathrm{~cm}$ の正方形て、、梁さ $70 \mathrm{~cm}$ であ。また、材質については側面がアクリル製、底板がアルミニ ウム製で、底板の下には熱フラックスを制御でをるラバーヒータ一を備えている。さらに、側面のアクリル 板の両面には、熱流入を防ぐために $3 \mathrm{~cm}$ 厚の発泡スチロール板をとりつけている。水槽内の水温は、水面か

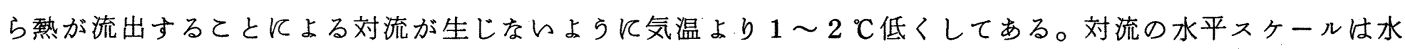
槽のスケールに比べ十分小さいが、非常に長い時間加熱を続けていると水槽の幅スケールの弱い流れが生じ る。そのために、実験はこの流れの影響が現われない時間内で行なった。さらに、実験スケールによる影響 を確かめるために、いくつかのスケールの異なる水槽での実験結果を比較してみると、水槽スケールによる 差は汪とんどみられなかった。

対流はアルミニウム粉末を水中に混濁させ、それに水平 るしくは垂直にスリット光を照射して可視化し、それをビ デオテープもしくは、35mmフィルムに撮って解析している。

\section{3 プリュームの発生について}

静止流体中で底板から加熟した場合にプリュームの発生 する様子を $\mathrm{ph}-1$ 亿示す。底板付近に熱伝導により温度が 高い層を形成し、その層の安定が崩れ頭部にサーマルを有 したブリュームが発生しているととがわかる。定常状態に 達した対流中では、底板付近に対流セルによる水平流が存 在するためにての様にはっきりと熱云導層が崩壊していく 様子はみられないが、水平流を持ち上げる様にしてプリュ 一ムが発生しているととから、潘同様な発生機構をるつ すのと思われる。対流内に発生するプリュームは、対流セ

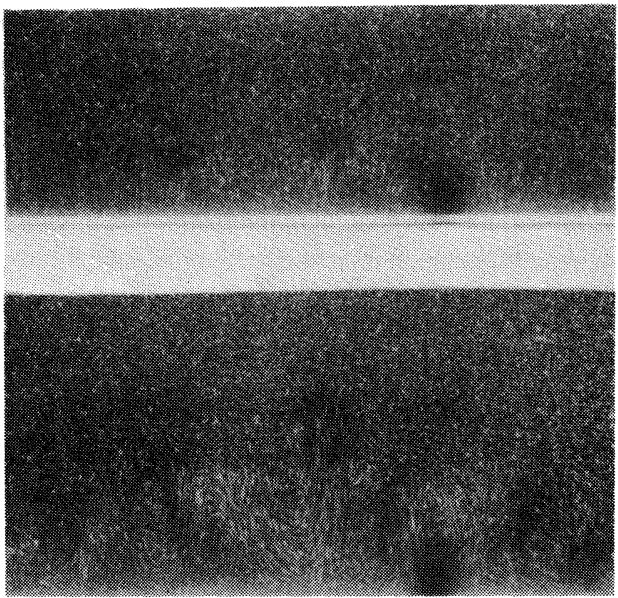

ph-1 静止流体中でのプリュームの発生 
几の水平流や下降流の

影響を受けるために、

完全にランダムには発

生しない。 $1 \mathrm{~cm}$ 幅のス

リット光中で $15 \mathrm{~cm} の 区$

間に発生したプリュー

ムについて、その発生

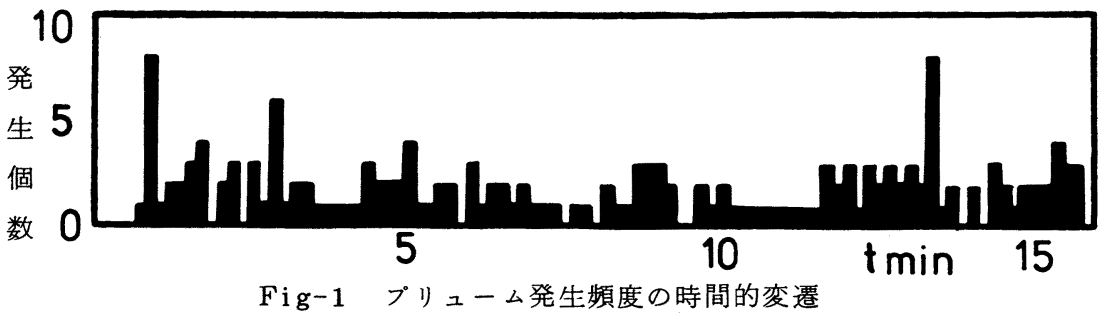

個数の時間的な変動をFig-1 亿示す。 発生個数に長周期の増减があるのは、対 流セ几自体が一力所飞留まらず変化して らるために、観測している場所に対流セ ル中の下降流が存在している場所が近ゔ くと発生が少なくなり、上昇流が存在す る場所が近うくと多くなるためである。

温度伝導率 $\kappa$ と水深 $\mathrm{d} て$ 無次元化した 単位面積、単位時間当りのブリュームの 発生頻度 $\mathrm{f}$ をフラックス型の Rayleigh 数 $\left(\alpha \mathrm{F}_{\mathrm{H}} / \rho \mathrm{c} \cdot \mathrm{g} \cdot \mathrm{d}^{4} / \kappa^{2} \nu\right.$ こてに $\alpha$ は体 膨張係数、 $\mathrm{F}_{\mathrm{H}}$ は単位面積当りの熱フラッ クス、っは密度、cは比熱、っは動粘性俰数、 $\mathrm{g}$ は重力加速度を示す。) 飞対し、整理 し、Fig-2に示す。これは、1 $\mathrm{cm}$ 幅のスリッ ト光線に映し出される部分のらち、15 cmの区 間につけて、1条件につき、5分から10分の

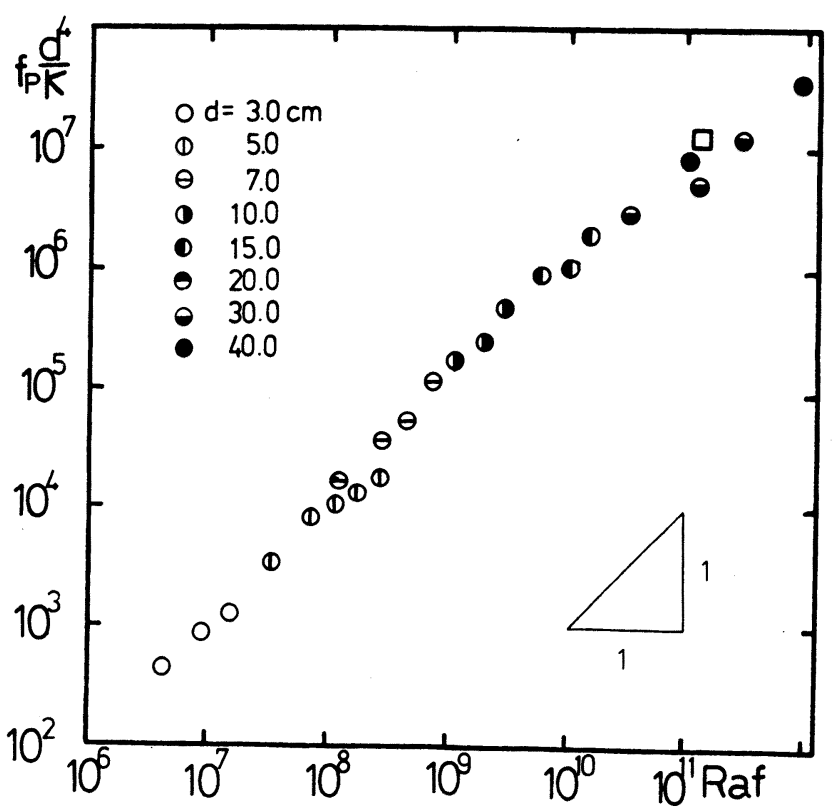

Fig-2 プリューム発生頻度とフラックス型 Rayleigh 数の関係 間に発生するプリュームの数を20ケース、アンサンブル平均して求めたものである。スリット幅を大をくし て、スリット幅による影響につんてる調べたが、ほ局じ所にプロットされた。また、測定範囲が小さいてとか ら、極めて強い下降流が存在し、プリュームが全く発生しなくなるととがあったが、プリュームの発生につ らて検討しているてとから、上層の流れの影響を必要以上に受けているるのについては削除してある。図中 には、ミネラルオイルを用い、水梁 $30 \mathrm{~cm}$ で行なったWhitehead と Chen ${ }^{2}$ ( $\square$ 印で示す)る同時に示してある。 図よりほ隹、

$$
\mathrm{f} \frac{\mathrm{d}^{4}}{\kappa}=1.1 \times 10^{-4} \mathrm{R}_{\mathrm{af}}
$$

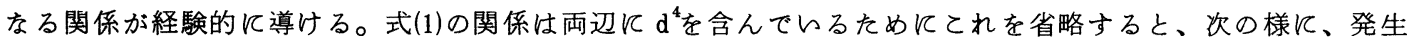
頻度に関しては水梁にほとんど影響されないといら結果を得る。

$$
\mathrm{f}=1.1 \times 10^{-4} \frac{\alpha \mathrm{F}_{\mathrm{H}}}{\rho \mathrm{c}} \frac{\mathrm{g}}{\kappa \nu}
$$

これは次の様に説明でをる。先に示した様に、ブリュームは底板付近に形成した熱伝導による層が崩壊して 生ずるために、その発生周期は一度崩壊した層が再び形成し、再度崩壊するまでの時間として表わされる。 対流が定常状態にある時に発生するプリュームは、静止流体中に発生するブリュームと異なり水平流速が存 在する中に発生するが、近似的に、静止流体中での安定問題の解を用いて検討してみる。この様に、下端が 固定境界、上端が流体に接している時には、Chandrasekhar $\sqrt[3]{ }$ よると、Rayleigh 数 $\left(=\alpha \Delta \mathrm{Tgh}^{3} / \kappa \nu\right.$, こ に、 $\Delta \mathrm{T}$ は下端と上層流体との間の温度差、hは熱伝導層の層厚を示す。）が 1100.7 (これを $\mathrm{R}_{\mathrm{ac}}$ 示す。) 
達した時に不安定が生じ、その時の限界層厚 $\mathrm{h}_{\mathrm{c}}$ と水平スヶールLとの間には、

$$
\mathrm{h}_{\mathrm{c}}=2.68 \mathrm{~L} / 2 \pi
$$

といら関係が存在する。さらに、一様な温度分布をるつ状態からの熱の供給時間 $\mathrm{t}$ と、熱の供給によっても たらされた過剩温度の分布を線型近似した時の層厚 $\mathrm{h}$ との間に $\mathrm{h}=\sqrt{ } \pi \mathrm{t} \mathrm{t}$ という関係が存在するために、 てれを限界状態での関係式 $\mathrm{R}_{\mathrm{a}}=\mathrm{R}_{\mathrm{ac}}$ に代入すると、限界状態での層厚と、それまでの時間 $\mathrm{t}_{\mathrm{c}}$ てついて次の 様な関係式が成立する。

$$
\begin{aligned}
& \mathrm{h}_{\mathrm{c}}=\left(\frac{\mathrm{R}_{\mathrm{ac}} \mathrm{N}_{\mathrm{u}} \cdot \nu \kappa^{2}}{\frac{\alpha \mathrm{F}_{\mathrm{H}}}{\rho \mathrm{c}} \mathrm{g}}\right)^{\frac{1}{4}} \\
& \mathrm{t}_{\mathrm{c}}=\left(\frac{\mathrm{R}_{\mathrm{ac} N \mathrm{u}}}{\frac{\alpha \mathrm{F}_{\mathrm{H}} \mathrm{g}}{\rho \mathrm{c} \nu} \pi^{2}}\right)^{\frac{1}{2}}
\end{aligned}
$$

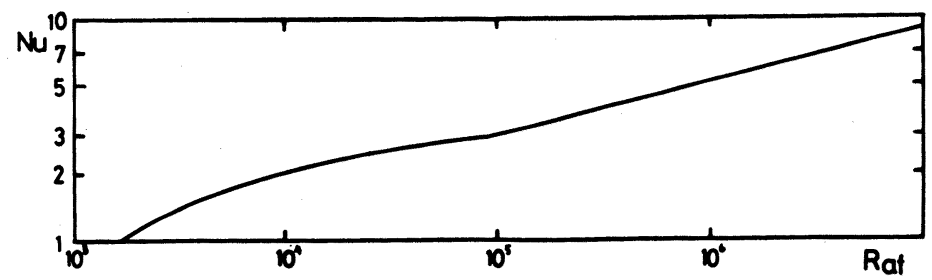

ここに、 $\mathrm{N}_{\mathrm{u}}$ は Nusselt 数

Fig-3 Nusselt 数とフラックス型Rayleigh 数の関係

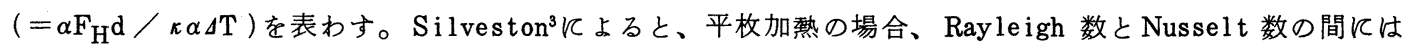
一義的な関係がある。乙れを、フラックス型の Rayleigh 数に対して再整理するとFig-3の様に表わされ、 この関係を延長すると、今回の実施範囲での Nusselt $\mathrm{t}$ 数は、汪㴗10〜20の範囲にあるてとがわかる。式(3)と (5)より、単位面積から単位時間当りに発生するプリュームの頻度は平均的に次の様に求まる。

$$
\mathrm{f}=\frac{1}{\mathrm{t}_{\mathrm{c}} \mathrm{L}^{2}}=\frac{1.796}{\mathrm{R}_{\mathrm{ac} \mathrm{Nu}}} \quad \mathrm{R}_{\mathrm{af}} \frac{\kappa}{\mathrm{d}^{4}}=(1.6 \sim 0.82) \times 10^{-4} \mathrm{R}_{\mathrm{af}} \frac{\kappa}{\mathrm{d}^{4}}
$$

式(6)の結果は、式(1)で示される実験結果とほ㕆一致しており、熱伝導によって形成された層が崩壊するすの と類似の機構でブリュームが発生しているととがわかる。

プリュームは、ph-1 の様に熱伝導によって底板付近 に形成された層の中に対流が起こり、発生する。したが って、プリュームの発生時における単位体積当りに及にさ れる浮力は、層の形成時飞流入した熱量が層の崩壊と同 時にブリュームとして上昇するとすれば次の様に求まる。

$$
\alpha \Delta \mathrm{Tg}=\frac{\frac{\alpha \mathrm{F}_{\mathrm{H}}}{\rho \mathrm{c}} \mathrm{g} \cdot \mathrm{t}_{\mathrm{c}} \mathrm{L}^{2}}{\mathrm{~h}_{\mathrm{c}} \mathrm{L}^{2}}=\left(\frac{\alpha \mathrm{F}_{\mathrm{H}}}{\rho \mathrm{c}} \mathrm{g}\right)^{\frac{3}{4}} \frac{1}{\pi}\left(\frac{\mathrm{N}_{\mathrm{u}} \mathrm{R}_{\mathrm{ac}} \nu}{\kappa^{2}}\right)^{\frac{1}{4}}
$$

プリューム内の温度を浮力に換算し、底板浮カフラッ クスに対して整理したすのをFig-4に示す。これは、全 水深を $7 \mathrm{~cm}$ 亿保ち、サーミスタを各高さ细定しておいて、 それから得られる出力変動分上り求循るのである。必 ずしも、プリューム中央部の温度を測定しているわけで はないので、可視化ょり判断して変動として得られたる ののらち、大きいるのから1/3のものについて平均した

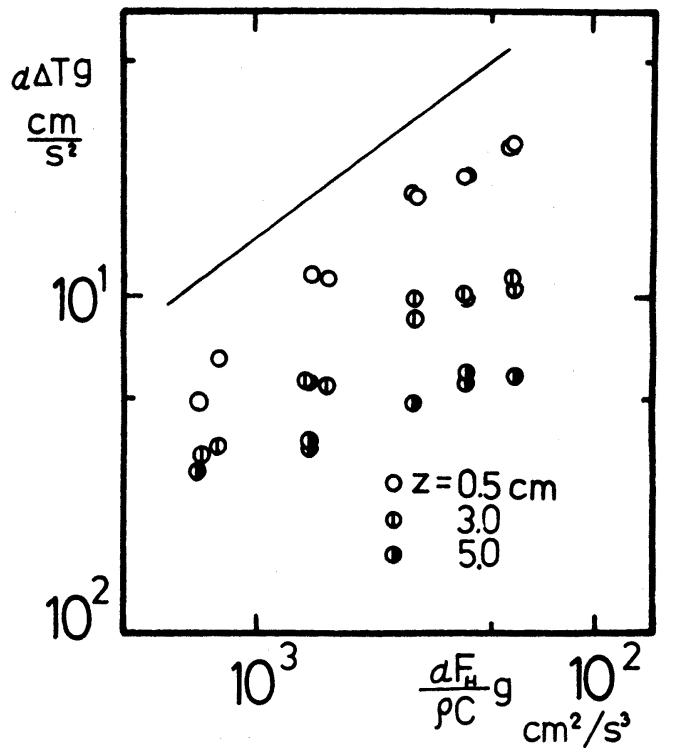
值を用いている。底板ょり $0.5 \mathrm{~cm}$ の高さで測られたものは Fig-4 プリューム内の浮力と浮カフラックスの関係 発生当初のプリュームの温度を表わしていると考允られる。ての実験值は式(7)上り求まる関係より小さくな っているが、熱伝導層に形成する対流の形状が一定していないてとなどを考慮すれば十分説明しているるの と思われる。また、測定位置が高くなる程、浮カフラックスの大きい場合に浮力の低下が著しいのは、浮力 フラックスの大をいるの程上昇流速が大をく、先端に形成する渦輪が強力なために、周囲流体を活発にブリ ューム内にとりとんでいるためである。 


\section{4 プリュームの継続時間}

発生したブリュームは周囲から流体を集めて上昇し続ける が、発生地点近傍飞別のプリュームが発生し、その新しいプ リュームの方の強度が元あったプリューム上り強くなると、 元あったプリュームはしだいに消減していく。近くに新しい プリュームが発生したために、以前よりあったプリュームが 減衰していく様子を ph-2 に示す。ての場合にる、ての様に 比較的遠い位置に別のプリュームが発生して消隇する場合と、 非常に近的位置飞別のプリュームが発生して消隇する場合と があり、後者の場合にはただちに合併してしまらために、医 㴗同地点に上昇流が存在し続けることになる。非常に近的位 置に別のプリュームが発生し、死とんど一体化してしまう場 合を除を、発生，消隇がはっきり識別できるプリュームにつ らて、継続時間Ppを無次元化し、フラックス型の Rayleigh 数に対して整理したるのがFig-5 亿示す図である。てれは、 一つの実験条件について約 30 個程度のプリュームの継続時間

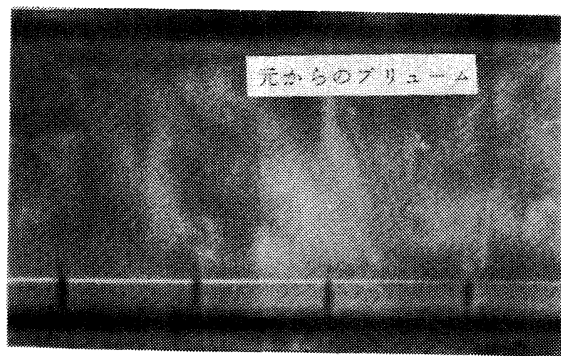
を平均して求めたるのである。図ょり、経験的に

$$
\mathrm{P}_{\mathrm{p}} \frac{\kappa}{\mathrm{d}^{2}}=7.5 \quad \mathrm{R}_{\mathrm{af}}^{-\frac{1}{2}}
$$

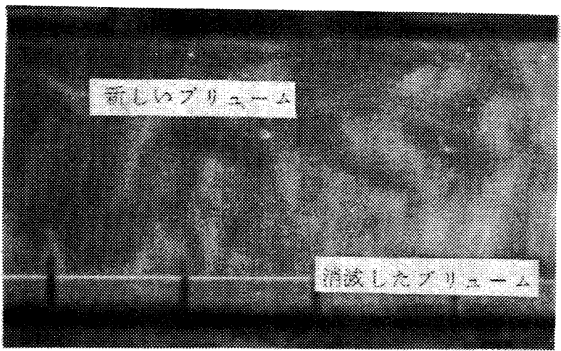

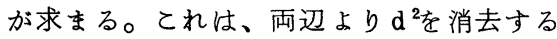
r、

$$
\mathrm{P}_{\mathrm{p}}=7.5\left(\frac{\alpha \mathrm{F}_{\mathrm{H}}}{\rho \mathrm{c}} \frac{\mathrm{g}}{\nu}\right)^{\frac{1}{2}}
$$

と表わされ、やはり水深に影響されないて とを示している。プリュームは多くの場合 近くに別のプリュームが発生したために消 隇しているてとから、ての関係は次の様に 考えるととがでをる。プリュームは発生時 には、潘 $\mathrm{L}^{2} の$ 範囲に一個の割合で発生す るが、発生後はさらに広的領域から流体を 集めて上昇する。乙れを $\mathrm{L}^{2} の \mathrm{~K}_{1}$ 倍の範囲か

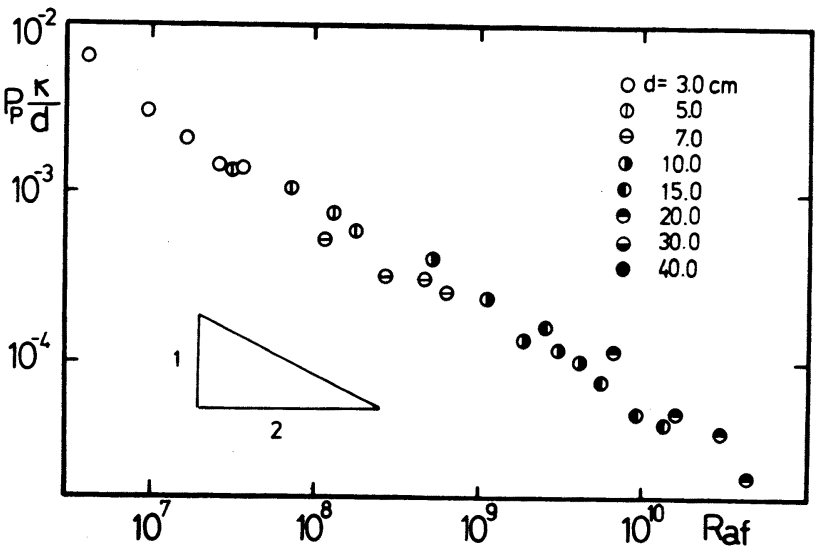

Fig-5 継続時間とフラックス型Rayleigh 数の関係 ら流体を集めて上㫒しているとすると、ての範囲内にプリュームの発生する頻度は、 $\mathrm{K}_{1} \mathrm{f} \mathrm{L}^{2}$ と表わされる。 新しいプリュームが発生すれば、ただちに古いブリュームが消減するわけではないので、補正係数 $\mathrm{K}_{2}$ 導入 すると、ブリュームの継続時間は次の様に求まる。

$$
\begin{aligned}
\mathrm{P} & =\frac{\mathrm{d}^{2}}{\kappa} \frac{\mathrm{K}_{2}}{\mathrm{~K}_{1}}\left(\frac{\mathrm{R}_{\mathrm{ac}} \mathrm{N}_{\mathrm{u}}}{\pi 2}\right)^{\frac{1}{2}} \mathrm{R}_{\mathrm{a}_{\mathrm{f}}^{-\frac{1}{2}}} \\
& =(33.4 \sim 47.2) \frac{\mathrm{d}^{2}}{\kappa} \frac{\mathrm{K}_{2}}{\mathrm{~K}_{1}} \mathrm{R}_{\mathrm{af}}^{-\frac{1}{2}}
\end{aligned}
$$

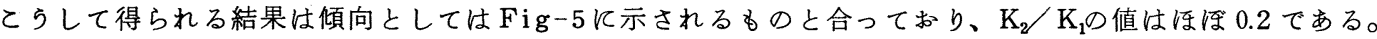

\section{5 大規模な対流セルの構造とプリュームの関係}

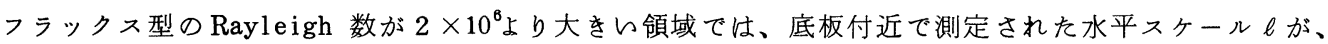


$\ell=7.1 \mathrm{~d}\left(\frac{\alpha \mathrm{F}_{\mathrm{H}}}{\rho \mathrm{c}} \frac{\mathrm{gd}^{4}}{\nu^{3}}\right)^{-\frac{1}{8}}$

で表わされる様な大規模なセ ル構造が存在するととが明ら かになっている。こうした構 造が水梁全体にわたって成立 するかどらかを示したすのが Fig-6である。これは、水面 付近にスリット光を水平に照 射し、下降流の存在する部分 が黒く現われるととを利用し

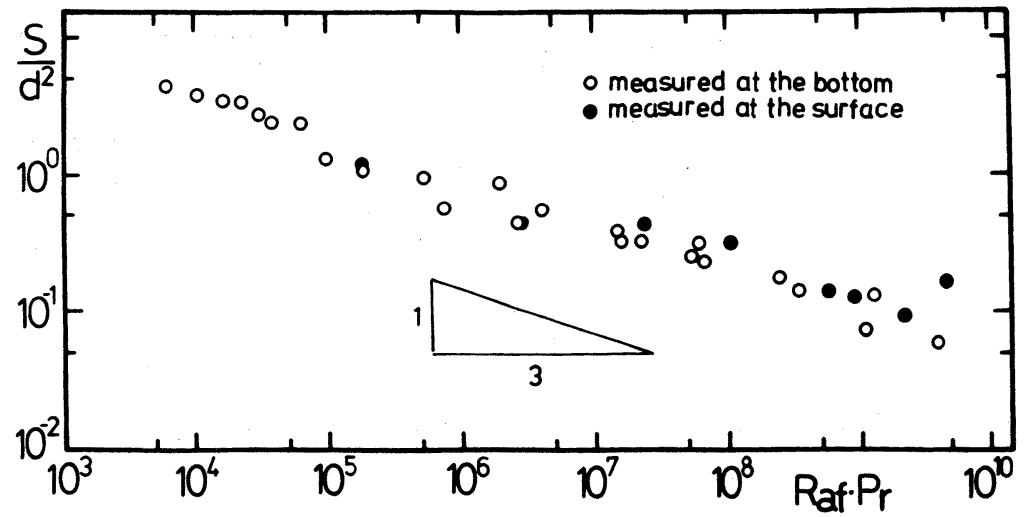

Fig-6 底面近傍と水面付近での対流セル断面積の比較

て水面での対流セルの形状を求め、その面積の平均值 $\mathrm{S}$ を計算

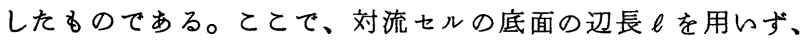
対流セルの底面積Sで示したのは、上部境界を自由水面にして らるために、セルの形状が丸みを帯び、辺の長さが正確に定ま らないためである。図より、 $\mathrm{R}_{\mathrm{af}} \mathrm{P}_{\mathrm{r}}^{-2}$ が、 $2 \times 10^{7}$ より小さい間 は、汪底板付近で観察されるセルの大きさと水面付近で観察 されるセルの大をさは等しいが、 $\mathrm{R}_{\mathrm{af}} \mathrm{P}_{\mathrm{r}}^{-2}$ がてれより大をい值 になると、水面付近で観察されるるのの方が大をくなっている。し かし、この程度の Rayleigh数の領域では、ほ庄柱状のセルが形成 しているといえる。従って、対流セルの上昇流の位置は水深全 体でほぼ一定であるために、発生したプリュームは対流セル内 に存在する水平流によって、傾斜させられたり発生位置を移動 させられたりして、対流セルの上昇流の存在する位置に導かれ、 他のプリュームと合併する。乙うして、いくつかのプリューム が集まって水面にまで到達する様な上昇流を形成していく。乙 のプリュームが合併していく様子を ph-3に示す。

次に、水深を $7 \mathrm{~cm}$ に保っておいて、各高さごとに単独で存在 するプリュームの数を調へ、全発生プリュームに対する比を

Fig-7 亿示す。底板 からの熱フラックスによらず、発生したプ リュームの 4 割前後のすのが、発生位置から他のプリュームに 合併してしまっており、㴗とんどのものが底板から高さ $3 \mathrm{~cm}$ での間に合併している様子がわかる。これはをた、単独では途 中で消隇してしまう様な大水深の場合でも、ての様にらくつか 合併しながら水梁規模の対流セルを構成していくことを示して レる。

この様に合併したブリュームす、プリューム自体が層流であ るために流体塊同士の場合は起こらず、多くのすのは識別でき る。底板で発生するプリュームの頻度に対する、水面付近で識 別でをるプリュームの頻度の割合をFig-8に示す。発生するプ リュームの強度は水深に医とんど影響されないために、水梁が 大をくなると、途中で消堿するプリュームの割合が増加するが
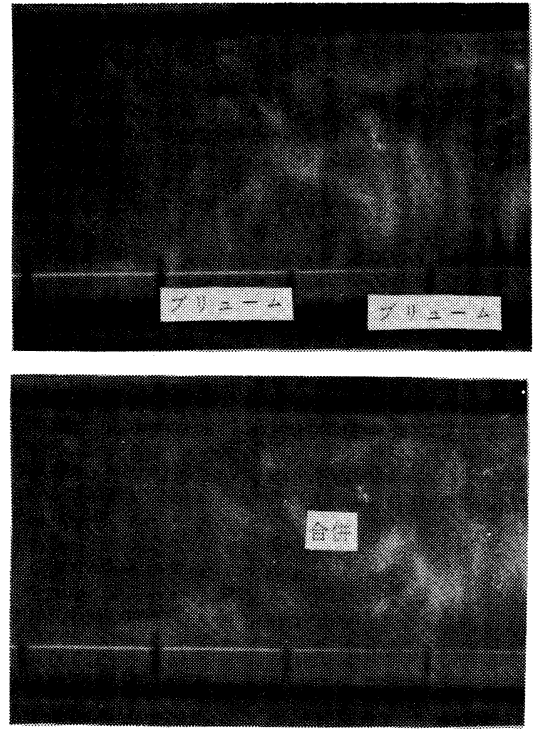

$\mathrm{ph}-3$ プリュームの合併

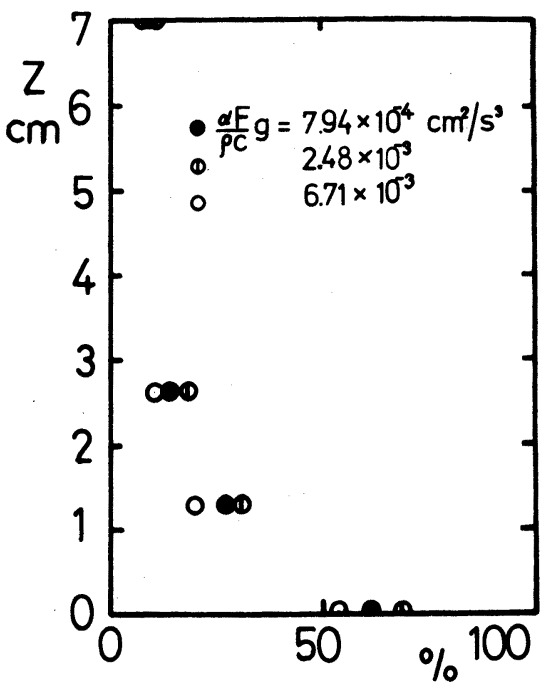

Fig-7 高さごとの単独で存在するプリュームの割合 
$\mathrm{R}_{\mathrm{af}}=5 \times 10^{\circ}$ ありまでは、 瓜㴗すへて到達しているてと がわかる。

以上の様に、プリュームが 集まって対流七几の上昇流の 部分を構成しているととが明 らかになったが、プリューム が合併した際の強度の追跡、 さらに、上昇流として水面に 到達し得るために必要なブリ ュームの数などについての考 察は今後の課題といえる。

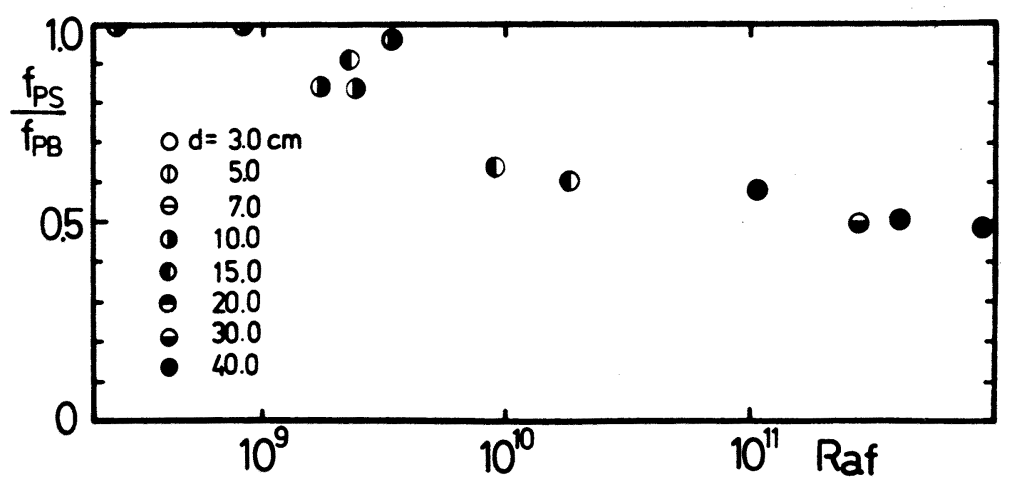

Fig-8 全プリュームの発生頻度に対する水面での到達割合

\section{6 結 論}

Rayleigh 数の非常に大きな領域て生じる対流を構成しているプリュームの発生機構および、そうしたプ リュームと対流セルとの関係につけて調へ、次の様な結論を得た。

1）定常な対流中に発生するプリュームは、熱伝導にょる層の安定が崩れた時に発生し、単位面積当りの発 生頻度 $\mathrm{f}$ は、 $\mathrm{f}=1.1 \times 10^{-4} \alpha \mathrm{F}_{\mathrm{H}} \mathrm{g} / \rho \mathrm{c} \kappa \nu$ と表わされ、水梁にほとんど影響されない。

2) 発生したプリュームは、その近傍に別の新しいブリュームが発生し、その強度が増すまて継続する。て の継続時間 $\mathrm{P}_{\mathrm{p}}$ は、 $\mathrm{P}_{\mathrm{p}}=7.5\left(\alpha \mathrm{F}_{\mathrm{H}} \mathrm{g} / \rho \mathrm{c} \nu\right)^{-\frac{1}{2}}$ で表わされ、やはり水深に棌とんど影響されない。

3）対流七几の水平スケールは、 $\mathrm{R}_{\mathrm{af}} \mathrm{p}_{\mathrm{r}}^{-2}<2 \times 10^{7}$ の領域で底板付近です水面付近ですとんどその断面 積は変わらないが、てれを越えるとしだいに水面付近て観察されるすのの方が大きくってくる。

4) 対流セル中で発生した汪とんどのブリュームは、セル内の水平流速のために移動し、対流七ルの上昇流 の発生している位置で他のプリュームと合併し、上界流を構成する。しかし、大部分のるのは合併後も識 別できる形で存在する。

最後に、本研究は、昭和 56 年度文部省科学研究費・奖励研究 $\mathrm{A}$ の援助を受けたととを記しておく。

\section{参 考 文 献}

1 浅枝隆, 玉井信行, 高橋由多加: 表層冷却時の対流形成飞関する研究, 第25回水理講演会論文集。 pp. $643-649,1976$.

2 Whitehead, J.A. and Chen, M.M. : Thermal instability and convection of a thin fluid layer bounded by a stably stratified region. J. Fluid Mech., vol. 40, part 3, pp. 549-576,1970.

3 Chandrasekhar, S. : Hydrodynamic and Hydromagnetic Stability . Oxford University Press , 1961. 